\title{
Why Small Businesses Were Hit Harder by the Recent Recession
}

\author{
Ayşegül Şahin, Sagiri Kitao, Anna Cororaton, and Sergiu Laiu
}

\begin{abstract}
Although both large and small businesses felt the sting of job losses during the 2007-09 downturn, small firms experienced disproportionate declines. A study of the recession's employment effect on small firms suggests that poor sales and economic uncertainty were the main reasons for their weak performance and sluggish recovery - problems that affected large firms too, but to a lesser degree. Although a tightened credit supply constrained some small firms, weak consumer demand for the firms' products and services was a more pressing factor, reducing revenues and dampening new investment spending.
\end{abstract}

\footnotetext{
he recent economic downturn saw an unprecedented deterioration in labor market conditions. From the December 2007 start of the recession to December $2009,{ }^{1}$ nonfarm payroll employment - the traditional measure of U.S. jobsdeclined by 8.4 million, a drop in levels unmatched in the entire postwar period. A closer look at the employment figures reveals that the recession's effect has not been uniform across firms of different sizes: small businesses have in fact been more adversely affected than large ones. Jobs declined 10.4 percent in establishments with fewer than fifty employees, compared with 7.5 percent in businesses with fifty-plus, while overall employment decreased 8.4 percent. This pattern is noticeably different from the trend of the 2001 recession.
}

Small (and young) firms are central to job creation and future recovery because they tend to grow faster than large businesses. ${ }^{2}$ It is therefore important to understand how the 2007-09 recession affected their performance. Moreover, assisting the turnaround of small businesses is critical for the improvement of labor market conditions, and such efforts can contribute to the overall U.S. recovery in the long run.

In this edition of Current Issues, we shed light on some of the factors that caused small businesses to be hit harder than large firms during the last downturn. We examine recent employment patterns and the industry composition of establishments by size. Because the credit markets also deteriorated during the recession, we explore possible links between credit availability and the performance of small firms. Our evidence is drawn from large surveys conducted at the national level and from established data series. (The box on page 2 describes our data sources in more detail.)

\footnotetext{
${ }^{1}$ According to the National Bureau of Economic Research (NBER), the recession ended in June 2009. However, payroll employment continued to decline throughout the end of that year.

${ }^{2}$ Haltiwanger, Jarmin, and Miranda (2010) show that this relationship is attributable mostly to young firms, as opposed to small ones, and highlight the importance of business start-ups and young businesses. We do not differentiate between small and young firms because of the scarcity of available data. However, since most young firms are small, our analysis captures the performance of both types.
} 


\section{Data Series and Surveys}

- The Business Employment Dynamics (BED) series, produced quarterly by the U.S. Bureau of Labor Statistics (BLS), tracks changes in nonfarm payroll employment in the private sector to calculate gross job flows. The BED follows job gains from openings and expansions and job losses from closings and contractions to reveal unemployment dynamics since 1992. Data are available at the establishment level and are classified by firm size and industry sector. The BED obtains data from the BLS Quarterly Census of Employment and Wages, which in turn collects data from approximately 98 percent of nonfarm payroll businesses in the United States. BED data are also compiled using quarterly state unemployment insurance records.

- The Business Dynamics Statistics (BDS) series is a longitudinal data set, produced by the U.S. Census Bureau, that contains data on the overall number of establishments, establishment size, initial size, age, and sector in the United States. Critical information on the decomposition of job creation and loss is contained in the BDS. The main drawback of the series is its significant time lag; the most recent data available are from 2005 , and data are released only annually.

- The Quarterly Financial Report (QFR), produced by the U.S. Census Bureau and available since 1987, is a survey of corporations of various sizes in the mining, manufacturing, and wholesale and retail trade industries. The quarterly time series provide a compilation of balance-sheet and income statement items, which give an overview of corporate profits and debt structure. Information is classified by industry and firm asset size.

- The survey produced by the National Federation of Independent Business (NFIB) gathers information on current business and economic conditions from approximately 2,000 small U.S. firms. Each month, the NFIB releases its Small Business Economic Trends Report, which includes a business optimism index to reflect overall small firm sentiment. In addition, specific categories, such as employment conditions, credit markets, earnings, and inventory levels, are reported on. We use the results of the survey conducted in November-December 2009.

- The Senior Loan Officer Opinion Survey, produced by the Board of Governors of the Federal Reserve System, has been a quarterly survey on the supply of and demand for different types of credit in the United States since 1997. Approximately sixty large domestic banks and twenty-four U.S. branches and agencies of foreign banks are asked qualitative questions about the credit conditions of businesses and households over the past three months. The survey offers an overview of changes in lending practices and the changes' effect on the credit markets.
Chart 1

\section{Cumulative Employment Changes since the Start of the 2007-09 and 2001 Recessions \\ By Business Size}

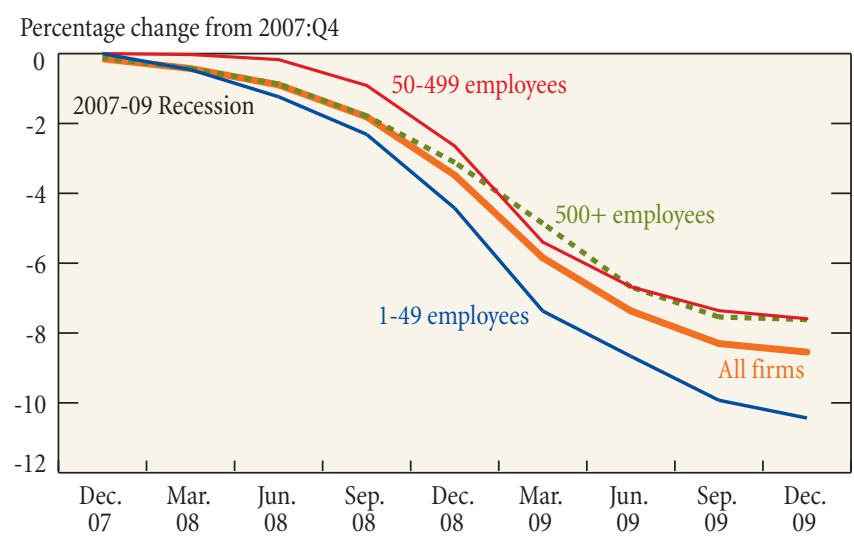

Percentage change from 2001:Q1

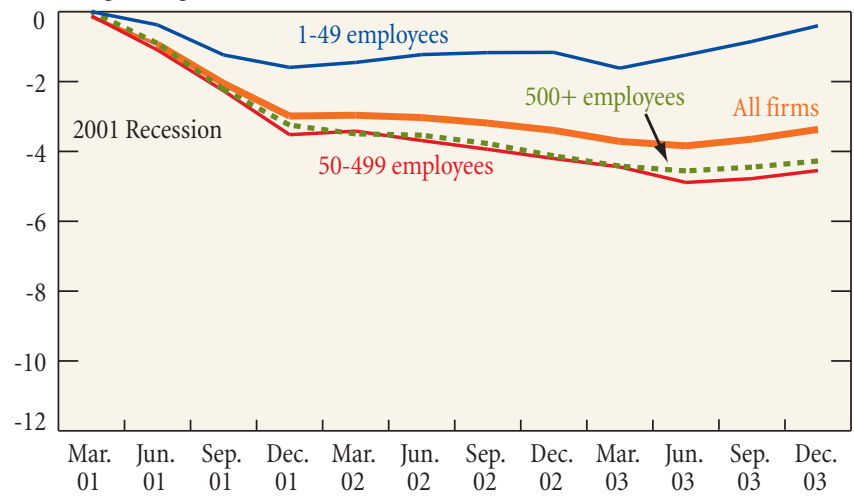

Source: U.S. Bureau of Labor Statistics.

While informal or one-time regional polls can also provide insights into the difficulties of small firms and thereby inform policy discussions of these issues, ${ }^{3}$ we focus on sources compiled over an extended period that permit comparisons of the data before and during the recession.

Our analysis initially considers two explanations for the recession's disproportionate effect on small firms: sectoral composition and credit availability. According to the sectoral composition hypothesis, if employment declines relatively more in sectors populated with small firms, in the aggregate these firms could account for a higher percentage of job losses. We find that sectoral composition fails to explain the weak performance of small firms, because the firms were hit harder than large ones regardless of sector. And while some small firms certainly experienced limited credit availability, this factor was a secondary driver of the difficulties they encountered. Instead, we find that demandside factors - notably, economic uncertainty and poor sales

\footnotetext{
${ }^{3}$ See the discussion in "Evidence from Surveys" on page 4 of this article.
} 


\section{Share of Small Businesses in Net Employment Change}

Percentage change in employment

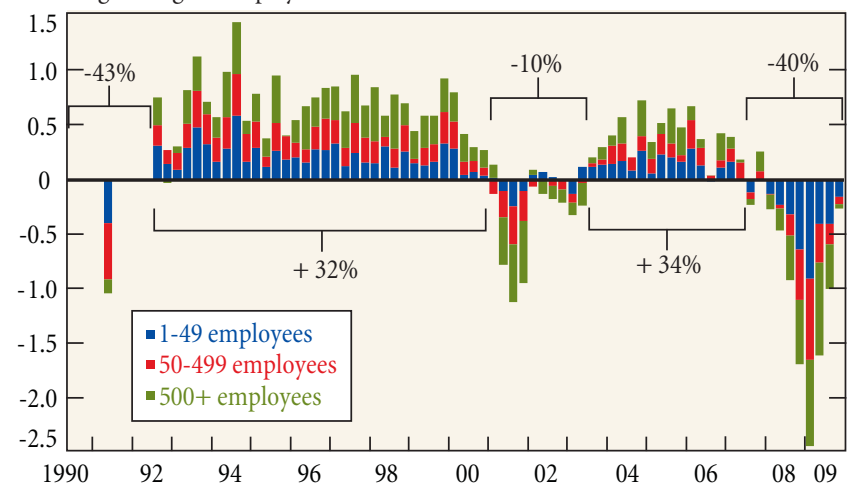

Source: U.S. Bureau of Labor Statistics.

stemming from reduced consumer demand-appear to be the most important reasons for the relatively weak performance and sluggish recovery of small firms.

\section{Employment by Firm Size and Industry Sector}

Nonfarm payroll employment began a downward trend in December 2007-the official start of the recession, according to the NBER. Our analysis of employment changes since the onset of the recession, reflected in the Business Employment Dynamics data series, shows that jobs decreased more in small establishments, which we define as having fewer than fifty workers, than in large ones. The top panel of Chart 1 presents the cumulative change in employment by business size relative to the level at the beginning of the 2007-09 recession. For comparison, the bottom panel shows the change from the start of the 2001 downturn. Together, the panels emphasize the severity of the recent recession in terms of the magnitude of jobs lost.

In addition to producing greater job losses, the 2007-09 recession differs from its predecessor in that small establishments were more negatively affected than larger ones. In the recent downturn, 40 percent of the overall employment decline can be attributed to losses at small businesses, compared with just 10 percent in the 2001 episode (Chart 2). ${ }^{4}$

One possible explanation for this result is the difference in the job-loss impact of recessions on individual sectors. To explore this sectoral composition hypothesis, we require information on employment patterns by firm size and industry sector. Because the BED series does not provide such information, we rely on the Business Dynamics Statistics data set, which offers data on employment gains and losses by size and sector for the 2007-09 period, albeit annually instead of quarterly.

\footnotetext{
${ }^{4}$ The chart is an updated version of the one posted on the Federal Reserve Bank of Atlanta's macroblog (see http://macroblog.typepad.com/macroblog/small-business).
}

The BDS series reveals that in 2007, manufacturing firms were the largest businesses in terms of employment, averaging forty-six workers (see table). By comparison, construction firms were among the smallest, with an average of twelve. Applying the sectoral composition hypothesis, we observe that a recession affecting the manufacturing industry more adversely should have a greater impact on larger firms in the aggregate, even if establishments are affected similarly regardless of size. By the same token, if the construction industry is harder hit by the downturn, we should expect small firms to be more adversely affected in the aggregate. Our examination of employment changes by firm size in each sector during the recession reveals that declines in small firms are larger than total sectoral percentage declines - with the exception of manufacturing, which experienced a uniform impact across firm sizes. Employment declines also are generally inversely correlated with firm size within sectors. Therefore, regardless of sector, small firms experienced greater employment declines than large firms did. The sectoral composition hypothesis thus does not explain the 2007-09 downturn's disproportionately negative effect on small businesses.

\section{Credit Constraints and Demand Factors}

Since the composition of job losses by sector does not account for the weak performance of small firms, we review evidence from several key surveys to assess the significance of other possible factors, such as credit frictions faced by these businesses. An extensive literature has examined the relationship between such frictions and the performance of small firms, including seminal work by Bernanke and Gertler (1989), Gertler and Gilchrist (1994), Kiyotaki and Moore (1997), and Bernanke, Gertler, and Gilchrist (1996). This literature suggests that small firms tend to rely more on credit obtained through intermediaries, such as banks, while larger firms have more varied sources of financing, such as direct credit, including the issuance of equity, corporate bonds, and commercial paper. According to balance-sheet data presented in the Quarterly Financial Report, bank loans represent two-thirds of the total debt of small firms, compared with onequarter for larger firms.

If credit market conditions deteriorate and the supply of bank credit dries up, the cost of external financing rises-especially for small firms, which would face difficulty raising funds for regular operations or new investments. Accordingly, we review this source of financing for small businesses and consider how it was affected by changes in credit conditions during the recent recession.

Bank loans have declined significantly since the start of the recession. In particular, commercial and industrial loans fell approximately 20 percent from March 2008 to June 2010. ${ }^{5}$ Moreover, credit card use by small business owners has contracted. The National Federation of Independent Business survey indicates that the number of small business owners using a credit

\footnotetext{
${ }^{5}$ Source: Federal Reserve Bank of St. Louis, FRED database.
} 


\section{Average Business Size and Sectoral Employment Declines}

\begin{tabular}{|c|c|c|c|c|c|}
\hline \multirow[b]{2}{*}{ Category } & \multirow{2}{*}{$\begin{array}{c}\begin{array}{c}\text { Average Business Size } \\
\text { (Number of Employees) }\end{array} \\
2007 \\
\end{array}$} & \multicolumn{4}{|c|}{ Employment Decline, 2007-09 (Percent) } \\
\hline & & Total & 1-49 Employees & 50-499 Employees & 500+ Employees \\
\hline Construction & 11.7 & -19.4 & -20.1 & -20.4 & -14.4 \\
\hline Manufacturing & 45.7 & -12.4 & -12.1 & -13.3 & -12.2 \\
\hline Transportation and public utilities & 22.1 & -4.8 & -7.9 & -4.5 & -4.0 \\
\hline Wholesale trade & 15.1 & -5.3 & -8.1 & -6.1 & -2.5 \\
\hline Retail trade & 17.0 & -3.2 & -4.7 & -5.3 & -1.8 \\
\hline Finance, insurance, and real estate & 11.4 & -6.3 & -8.5 & -3.9 & -6.0 \\
\hline Services & 17.3 & -0.8 & -1.6 & -0.2 & -0.5 \\
\hline All & 17.1 & -4.4 & -5.8 & -5.1 & -3.3 \\
\hline
\end{tabular}

card to pay business expenses decreased 7 percentage points from 2008 to 2009. The deterioration of both real estate prices and the mortgage market has also negatively affected small business financing. Indeed, approximately 16 percent of small business owners have taken out home equity loans to finance operations or have used their homes as collateral for purchasing assets. The plunge in real estate prices has thus put further downward pressure on the borrowing capacity of these individuals.

The question arising from these developments is the degree to which a credit-related downturn led to a shrinkage in financing for small firms because the firms experienced reduced access to credit, or because they had less of a demand for loans. During downturns, sales and profitability typically decline as firms face increased economic uncertainty and difficulty estimating consumer demand for their products and services. Business owners, mindful of an inability to expand, are more cautious about taking on debt, and their demand for credit decreases.

We answer this question by first considering the credit-supply channel. Theory suggests that when credit declines in the banking system, "flight-to-quality" phenomena likely emerge. That is, banks become more selective and risk-averse when extending loans and they curtail lending to riskier borrowers. Hence, small firms, which rely more on external financing and tend to be riskier, are more likely to be affected by a credit crunch. To explore this issue fully, we require detailed information on lending, such as the number of small business loan applications, the percentage of loans granted at different interest rates, and collateral requirements. In addition, details about the performance of small businesses are helpful in assessing the effect of credit constraints. Such data, however, are not readily available. For this reason, we rely on evidence from established national surveys to assess the effect of credit frictions and demand factors on small firms.

\section{Evidence from Surveys}

Did lender behavior contribute to especially tight credit conditions for small firms? According to data in the Quarterly Financial Report survey, the total debt of small manufacturing firms has dropped significantly, while large manufacturing firms have seen theirs rise. This pattern could be attributable to discrimination by lenders; that is, some of the contraction in debt—caused by lenders tightening loan standards and interest rates - could have resulted from a decline in credit supply to small firms.

We investigate the issue of lender discrimination using information in the Senior Loan Officer Opinion Survey, which asks questions specifically on business credit conditions. Survey responses on the tightening of loan standards and on changes in loan spreads are plotted in Chart 3. (Following the survey's classifications, we define firms with annual sales of less than $\$ 50$ million as small.)

The chart shows that, regardless of firm size, the number of respondents that reported tightening rose immediately after the start of the recent recession, but has since returned to its prerecession level. A similar trend is observed in loan spreads. Note that the survey tracks the number of respondents who report a tightening of loan standards and an increase in loan spreads, but not information on the degree of tightness or the actual rise in spreads. Despite this limitation, the survey indicates that firms of different sizes have experienced similar changes in the loan standards and interest rate spreads imposed by banks, and that the prevalence of a decrease in credit supply is similar across all firms. ${ }^{6}$ This result suggests that a tightened credit supply is not the main reason why the small firms were affected more adversely than large ones during the recession. To be sure, informal

\footnotetext{
${ }^{6}$ Steindel and Brauer (1994), studying the effects of a decline in credit on business activity during the 1990-91 recession, find little evidence of an association between weakness in small firms and credit market tightness.
} 
Chart 3

\section{Changes in Loan Standards and in Spreads of Loan Rates}

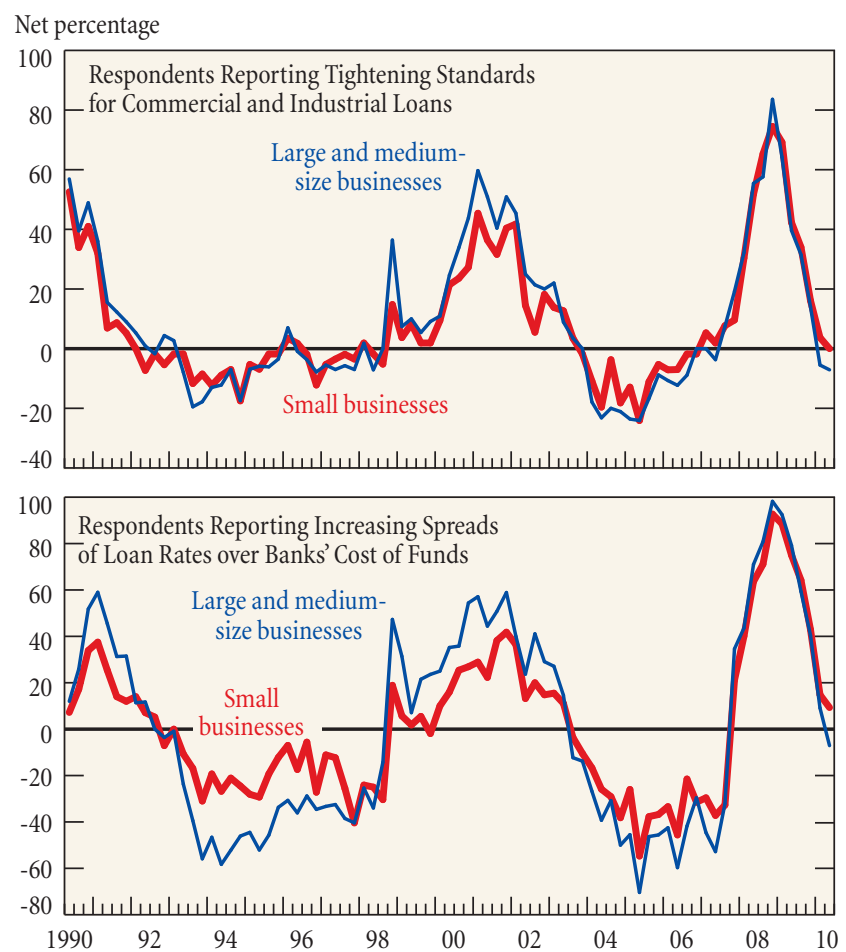

Source: Board of Governors of the Federal Reserve System, Senior Loan Officer Opinion Survey.

survey evidence indicates that in some areas of the country, many small firms have had difficulty obtaining credit. ${ }^{7}$ However, the established data series and surveys at the national level suggest that credit frictions played a secondary role overall.

Turning to demand factors, we examine data in the National Federation of Independent Business survey, which continuously monitors economic conditions faced by small businesses. In particular, owners of small businesses are regularly asked to identify the most important problem associated with weak economic conditions (Chart 4). The survey reveals that the share of small businesses reporting poor sales as the most important problem

\footnotetext{
${ }^{7}$ In 2010, the Federal Reserve System's Community Affairs Offices hosted a series of focus groups and regional meetings with small business owners, small business trade groups, and community development financial institutions. Participants at these meetings reported a tightening of lending standards and an increase in collateral requirements, including personal guarantees. In the absence of detailed evidence on loan applications, it is difficult to determine how representative these reports are. For more information on the Fed's regional meetings and focus groups, see "Addressing the Financing Needs of Small Businesses: Summary of Key Themes from the Federal Reserve System's Small Business Meeting Series," a report appended to Federal Reserve Chairman Ben Bernanke's HumphreyHawkins testimony (see http://www.federalreserve.gov/newsevents/conferences/ sbc_small_business_summary.pdf).
}

Chart 4

\section{Single Most Important Problem Associated with Weak Economic Conditions As Reported by Small Businesses}

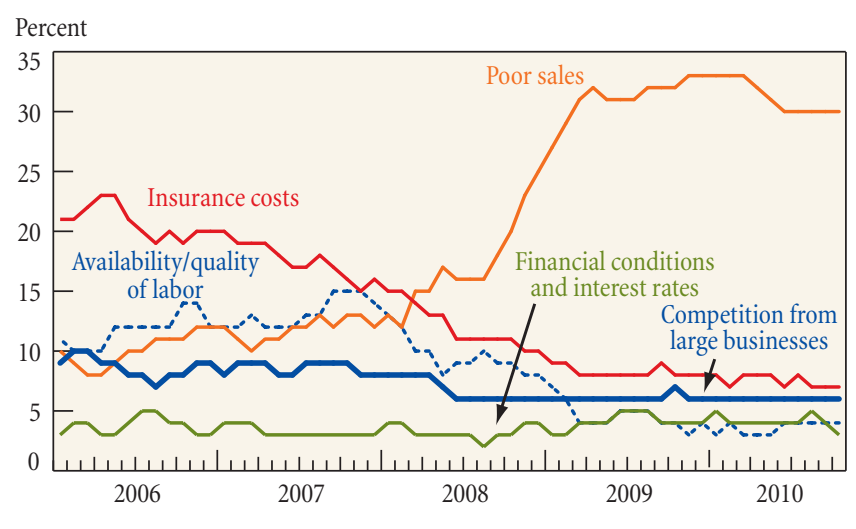

Source: National Federation of Independent Business.

has increased dramatically, while the relative significance of other factors, such as insurance costs and the availability and quality of labor, has diminished. Few establishments cite financial conditions and interest rates as the main obstacle, a trend that has remained stable throughout the recession. Although some firms report greater difficulty obtaining credit, the chief reason for their sluggish performance appears to be a lack of current and expected future demand for their goods and services, as reflected in the firms' concerns about poor sales. This reduced consumer interest in the products of small firms likely lowered the firms' demand for credit. In these scenarios, firms do not have the ability to invest and thus have little need to borrow.

While the NFIB data do not permit comparisons between small and large businesses, the concerns of small firms are borne out by data in the Quarterly Financial Report, which contrasts the performance of these firms with that of larger ones. The QFR collects balance-sheet information on U.S. corporations, classified by asset size. ${ }^{8}$ Following the QFR classifications, we define firms with total assets of less than $\$ 50$ million as small. We use information from the QFR to compare how small and large firms have fared according to four important balance-sheet items: total debt, sales, inventory, and fixed investment (Chart 5).

- Total debt of small firms started to decline in fourth-quarter 2008 and has not begun to recover as of second-quarter 2010. Meanwhile, total debt of large firms (with more than $\$ 50$ million in total assets) continued to increase throughout the recession.

\footnotetext{
${ }^{8}$ The QFR is also used by Gertler and Gilchrist (1994) to analyze the effect of monetary contractions on small and large manufacturing firms. The survey covers only manufacturing, mining, and wholesale and retail trade industries, so conclusions based on it are somewhat limited.
} 
Chart 5

Changes in Total Debt, Sales, Inventory, and Fixed Investment

By Business Size
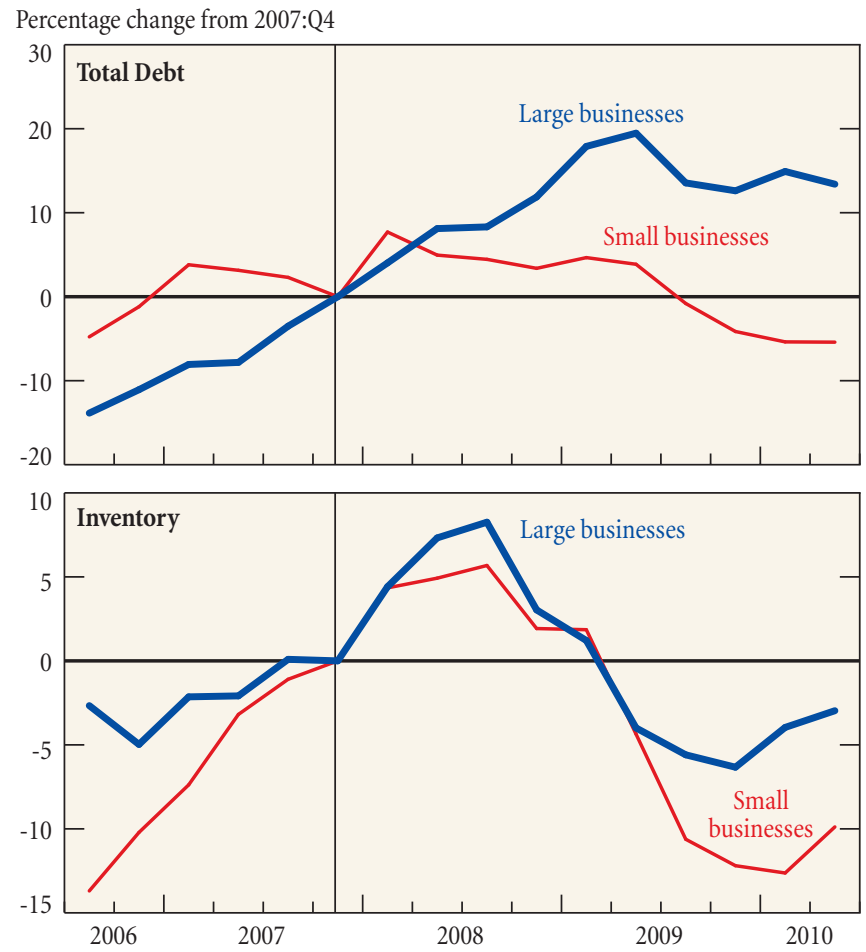

Percentage change from 2007:Q4
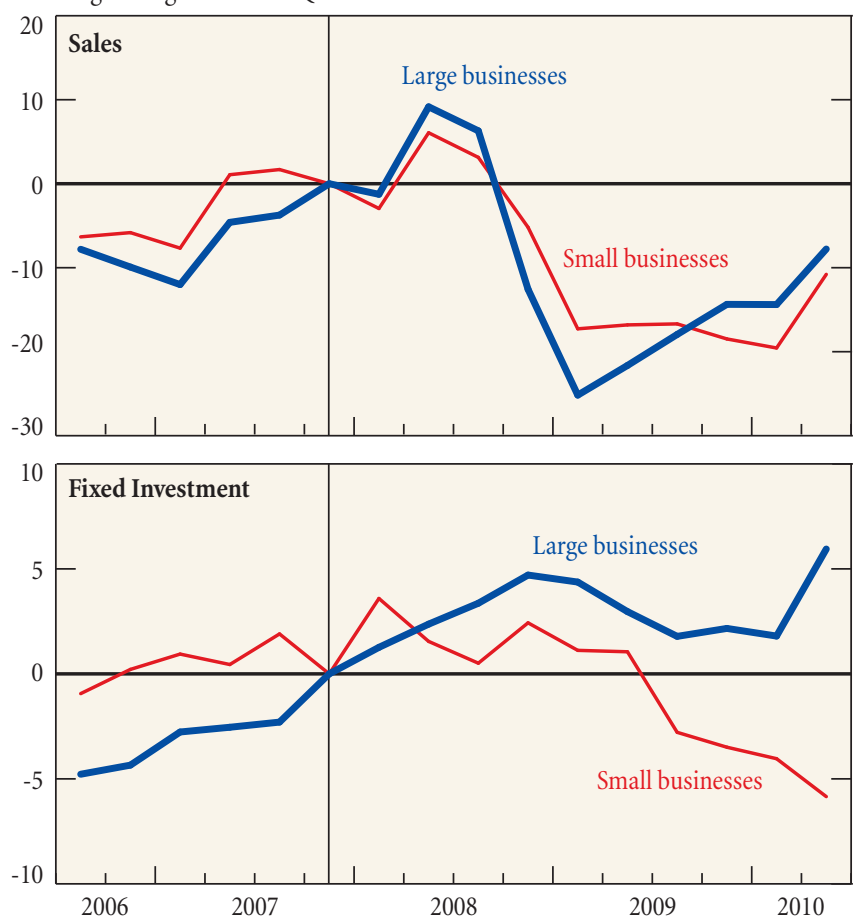

Source: U.S. Census Bureau.

- The behavior of sales has been similar for small and large firms until recently. Sales started to recover among large manufacturing firms in second-quarter 2009, while sales of small firms have lagged and their recovery has been sluggish.

- Growth in inventories for small and large firms has fallen since fourth-quarter 2008, but it has declined more sharply for small firms. The level of inventories in these firms remains more than 10 percent below the year-end 2007 level, suggesting that small businesses managed the fluctuation in sales through greater inventory adjustment. In particular, the recent recovery of sales in large firms has been accompanied by a rise in total debt and an increase in inventory, while small firms are still confronted with tepid sales growth, low inventory levels, and declining total debt.

- Fixed investment dropped significantly among small firms, and there has been no sign of recovery. In contrast, fixed investment by large firms has shown a sharp increase.

The question whether small firms are prevented from increasing investment by a lack of available credit, or are simply choos- ing not to increase investment because of lower sales and reduced profitability, is a difficult one, complicated by a lack of detailed data on small business loan applications and bank lending terms. Our review of the available evidence from national data sources suggests that diminished consumer demand for products and services - in turn leading to a reduced demand for credit-has affected small firms more than large ones during the recent downturn and contributed to their overall weak performance.

\section{Conclusion}

The 2007-09 downturn has had a deeper employment impact on small businesses than on large ones. Small firms attribute the relatively steep decline in jobs mostly to poor sales and economic uncertainty - problems that also affected large firms, but to a lesser degree. Tightened access to credit and adverse financial conditions also constrained small firms but a more important factor was the decline in new investment and associated financing in the face of weak consumer demand for the firms' products and services. 
The recovery of small businesses is a significant component of job creation and the overall economic recovery. Our findings do not imply that credit availability is unimportant for small and young firms. Rather, as sales conditions improve and credit demand picks up, access to credit by small firms will help ensure that high-potential businesses and entrepreneurs can thrive.

\section{References}

Bernanke, Ben, and Mark Gertler. 1989. "Agency Costs, Net Worth, and Business Fluctuations." American Economic Review 79, no. 1 (March): 14-31.

Bernanke, Ben, Mark Gertler, and Simon Gilchrist. 1996. “The Financial Accelerator and the Flight to Quality." Review of Economics and Statistics 78, no. 1 (February): 1-15.
Gertler, Mark, and Simon Gilchrist. 1994. "Monetary Policy, Business Cycles, and the Behavior of Small Manufacturing Firms." Quarterly Journal of Economics 109, no. 2 (May): 309-40.

Haltiwanger, John C., Ron S. Jarmin, and Javier Miranda. 2010."Who Creates Jobs? Small vs. Large vs. Young.” NBER Working Paper no. 16300, August.

Kiyotaki, Nobuhiro, and John Moore. 1997. “Credit Cycles.” Journal of Political Economy 105, no. 2 (April): 211-48.

Steindel, Charles, and David Brauer. 1994. "Credit Supply Constraints on Business Activity, Excluding Construction.” Unpublished paper, Federal Reserve Bank of New York.

\section{ABOUT THE AUTHORS}

Ayşegül Şahin is an assistant vice president, Sagiri Kitao a senior economist, and Anna Cororaton an assistant economist in the Federal Reserve Bank of New York's Research and Statistics Group; Sergiu Laiu is an associate business support analyst in the Markets Group.

The views expressed in this article are those of the authors and do not necessarily reflect the position of the Federal Reserve Bank of New York or the Federal Reserve System.

Current Issues in Economics and Finance is published by the Research and Statistics Group of the Federal Reserve Bank of New York. Linda Goldberg and Erica L. Groshen are the editors.

Editorial Staff: Valerie LaPorte, Mike De Mott, Michelle Bailer, Karen Carter

Production: Carol Perlmutter, David Rosenberg, Jane Urry

Subscriptions to Current Issues are free. Send an e-mail to Research.Publications@ny.frb.org or write to the Publications Function, Federal Reserve Bank of New York, 33 Liberty Street, New York, N.Y. 10045-0001. Back issues of Current Issues are available at http://www.newyorkfed.org/research/current_issues/.

\section{Check Out Our Blog: Liberty Street Economics}

Readers looking for timely and frequent posts on a range of topics will enjoy Liberty Street Economics. The blog offers research by our large staff of economists, with a less technical style that makes their insights accessible to a wide audience.

Liberty Street Economics also publishes reader comments and author responses, with the goal of broadening our dialogue with you.

Recent posts include:

- “Commodity Prices and the Mistake of 1937: Would Modern Economists Make the Same Mistake?” Gauti Eggertsson

- Global Banks and Their Internal Capital Markets during the Crisis," Nicola Cetorelli and Linda S. Goldberg

- "Would a Stronger Renminbi Narrow the U.S.-China Trade Imbalance?" Matthew Higgins and Thomas Klitgaard

- "Which Firms Have Flexible Prices?” Rebecca Hellerstein and Pinelopi Goldberg

So be sure to visit our blog-we welcome your comments!

\section{libertystreeteconomics.newyorkfed.org}

